\title{
En Bloc Resection
}

National Cancer Institute

\section{Source}

National Cancer Institute. En Bloc Resection. NCI Thesaurus. Code C139567.

A surgical procedure in which organs or tissues are removed as a whole. 